\title{
Human uterine myometrial smooth muscle cell proliferation and vascular endothelial growth-factor production in response to platelet-derived growth factor
}

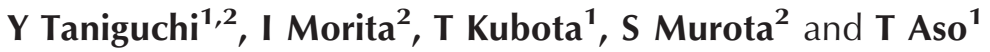 \\ ${ }^{1}$ Comprehensive Reproductive Medicine, Graduate School, Tokyo Medical and Dental University, 1-5-45, Yushima, Bunkyo-ku, Tokyo, Japan \\ ${ }^{2}$ Cellular Physiological Chemistry, Graduate School, Tokyo Medical and Dental University, 1-5-45, Yushima, Bunkyo-ku, Tokyo, Japan \\ (Requests for offprints should be addressed to I Morita; Email: morita.cell@tmd.ac.jp)
}

\begin{abstract}
It has been recognized that tissue-specific growth factors and angiogenic factors play important roles in the growth of tumors and in the tissue-repair system. In uterine myometrial smooth muscle cells, it has also been reported that the platelet-derived growth factor (PDGF) binds to PDGF receptors and stimulates proliferation. In this paper, we examine whether or not PDGF is able to stimulate production of vascular endothelial growth factor (VEGF) in cultured human myometrial smooth muscle cells. PDGF treatment enhanced immunoreactive VEGF production as well as cell proliferation. Production of VEGF121 and VEGF165 in the cells was detected by reverse transcription-polymerase chain reaction analysis, but the PDGF treatment did not change the ratio of VEGF165 to VEGF121. The effect of PDGF on cell
\end{abstract}

proliferation leveled off at $10 \mathrm{ng} / \mathrm{ml}$, whereas its effect on VEGF production continued to increase linearly at concentrations above $10 \mathrm{ng} / \mathrm{ml}$. Upon treatment of the cells with antibody against VEGF, the cell proliferation increased linearly even at PDGF concentrations above $10 \mathrm{ng} / \mathrm{ml}$. The enhanced $\left[{ }^{3} \mathrm{H}\right]$ thymidine incorporation by PDGF was abolished by either mitogen-activated protein kinase kinase (MAPKK) inhibitor or protein kinase C (PKC) inhibitor. In contrast, VEGF production was abolished by MAPKK inhibitor, but not by PKC inhibitor. These results indicate that PDGF stimulates both cell proliferation and VEGF production in partly different signal pathways, and thus PDGF might play a role in the physiology and pathology of the myometrium.

Journal of Endocrinology (2001) 169, 79-86

\section{Introduction}

Tissue organization is known to be maintained by both cellular proliferation and cellular differentiation. The uterine myometrium is a quiescent tissue composed primarily of differentiated smooth muscle cells, but in leiomyomata the smooth muscle cells undergo proliferation. Platelet-derived growth factor (PDGF) is a mitogen for smooth muscle cells and it is found in human tissues predominantly as a heterodimer of PDGF-A and PDGF-B. PDGF has been localized within human uterine smooth muscle cells (HUSMCs) (Rossi et al. 1992, Mangrulkar et al. 1995). Moreover, the $\beta$-receptor for PDGF was also found in the myometrium, and under certain conditions (including in leiomyomata), PDGF is thought to have a crucial role in the proliferation of HUSMCs (Rossi et al. 1992). Harrison et al. (1995) reported the expression of the mRNA of the angiogenic factor, vascular endothelial growth factor (VEGF), in human uterine smooth muscle, and they speculated that VEGF plays a part in angiogenesis within the tumor and in the surrounding myometrium. PDGF raises VEGF expression in vascular smooth muscle cells (Brogi et al. 1994, Stavri et al. 1995). However, little is known of the mechanism by which PDGF induces VEGF secretion. In this study, we show that PDGF can stimulate proliferation and VEGF secretion in HUSMCs and that the cellular organization of tube-like formation in endothelial cells is stimulated by VEGF secreted from PDGF-treated HUSMCs. In addition, our results show that PDGF stimulated both HUSMC proliferation and VEGF production through partly different signal pathways.

\section{Materials and Methods}

\section{Human myometrial cell culture}

Myometrial tissues were collected from 16 women undergoing hysterectomy at the Tokyo Medical and Dental University. Patients 40-48 years of age (median age, 45 years) were included in this study. None was pregnant and all had regular menstrual cycles. Informed consent was obtained from each patient and the investigation was approved by the local ethical committee of Tokyo Medical 
and Dental University. Primary myometrial cells from the human myometrium immediately after the hysterectomy were obtained and cultured using the explant method described previously, as modified by us (Chen et al. 1973, Moss \& Benditt 1975, Kawaguchi et al. 1985). The myometrial tissue was cut further with a scalpel into $1 \mathrm{~mm}$ pieces in calcium-magnesium-free PBS. Two pieces of the tissue were placed in $35 \mathrm{~mm}$ Petri dishes (Becton Dickinson Labware, Franklin Lakes, NJ, USA) and incubated at $37{ }^{\circ} \mathrm{C} / 5 \% \mathrm{CO}_{2}$ in air with Dulbecco's modified Eagle's medium (DMEM; Life Technologies, Rockville, MD, USA) or phenol-red-free DMEM (Life Technologies) supplemented with 10\% fetal bovine serum (FBS) (JRH, Lenexa, KS, USA). The medium was changed every 3 days. After becoming confluent, cells were subcultured. They were transferred to other $10 \mathrm{~cm}$ Petri dishes by using calcium-magnesium-free PBS supplemented with 0.05\% trypsin/EDTA (Life Technologies/ Dojindo, Kumamoto, Japan). Cells were studied from the 1 st to the 8 th passage.

HUSMCs were seeded at sub-confluence in a 24-well FALCON plate (Becton Dickinson Labware) in DMEM for $24 \mathrm{~h}$, then washed and incubated in serum-free DMEM for $24 \mathrm{~h}$. The media were removed and the cells incubated for $24 \mathrm{~h}$ in serum-free DMEM containing $0-50 \mathrm{ng} / \mathrm{ml}$ recombinant human PDGF-BB (homodimer of PDGF-B) (Sigma, St Louis, MO, USA), $20 \mathrm{ng} / \mathrm{ml}$ VEGF (human recombinant VEGF165) (Pepro Tech, London, UK) or 0-100 nM 17 $\beta$-estradiol (Sigma). Some cells were incubated in the presence of an additional $3 \mu \mathrm{g} / \mathrm{ml}$ VEGF-neutralizing antibody (IBL, Gunma, Japan). Cells were preincubated for $30 \mathrm{~min}$ in the presence of either $100 \mu \mathrm{M}$ mitogen-activated protein kinase kinase (MAPKK) inhibitor (PD 098059; Biomol, Plymouth Meeting, PA, USA) or $5 \mu \mathrm{M}$ protein kinase C (PKC) inhibitor (GF 109203X; Sigma) and were then treated with PDGF (Toullec et al. 1991, Alessi et al. 1995, Pang et al. 1995).

\section{${ }^{3}$ H] thymidine incorporation}

The proliferation of HUSMCs and human umbilical vein endothelial cells (HUVECs) after incubation for $24 \mathrm{~h}$ in serum-free DMEM in the presence or absence of PDGF or VEGF was determined by $\left[{ }^{3} \mathrm{H}\right]$ thymidine incorporation. $\left.{ }^{3} \mathrm{H}\right]$ thymidine (Amersham, Buckinghamshire, UK) was added at a concentration of $1 \mu \mathrm{Ci} / \mathrm{ml}$ for each well and incubated for $2 \mathrm{~h}$. The cultures were washed with calcium-magnesium-free PBS. Cells were solubilized in $500 \mu \mathrm{l} 0.15 \mathrm{~N} \mathrm{NaOH}$ for $2 \mathrm{~h}$ and neutralized in $35 \mu \mathrm{l} 10 \% \mathrm{CH}_{3} \mathrm{COOH}$. After the addition of $5 \mathrm{ml}$ PICO-FLUORTM 40 (Packard Instruments, Meriden, CT, USA), their radioisotope content was determined with a TRI-CARB 2750 TR/LL liquid scintillation counter (Packard Instruments).

\section{Enzyme-linked immunosorbent assay (ELISA)}

Secreted VEGF proteins in cultured medium from HUSMCs after incubation for $24 \mathrm{~h}$ in serum-free DMEM in the presence or absence of PDGF or $17 \beta$-estradiol were determined by using the Quantikine human VEGF ELISA kit (R\&D Systems, Minneapolis, MN, USA) according to the manufacturer's protocol. This assay employs a murine monoclonal antibody against VEGF and the quantitative sandwich enzyme immunoassay technique. It recognizes both natural and recombinant human VEGF and detects concentrations in the range $15 \cdot 6-1000 \mathrm{pg} / \mathrm{ml}$.

\section{Reverse transcription-polymerase chain reaction (RT-PCR)}

The expression of VEGF isoforms was detected using RT-PCR. Serum-starved, sub-confluent cells in $10 \mathrm{~cm}$ Petri dishes were incubated for $24 \mathrm{~h}$ with $(20 \mathrm{ng} / \mathrm{ml})$ or without PDGF. Total RNA was isolated from myometrial smooth muscle cells by using the Catrimox 14TM RNA isolation kit (TaKaRa, Tokyo, Japan). A RT-PCR was performed with an RNA PCR kit (AMV Version 2.1 (TaKaRa). Total RNA (1 $\mu \mathrm{g})$ was reverse-transcribed using Random 9-mers for 1 cycle of $30^{\circ} \mathrm{C}$ for $10 \mathrm{~min}$, $55^{\circ} \mathrm{C}$ for $30 \mathrm{~min}, 99^{\circ} \mathrm{C}$ for $5 \mathrm{~min}$ and $5{ }^{\circ} \mathrm{C}$ for $5 \mathrm{~min}$. The PCR was performed with primers from exon 1 (sense, 5'-TGCCTTGCTGCTCTACCTCC-3') and exon 8 (antisense, 5'-TCACCGCCTCGGCTTGTCAC-3') of VEGF. The PCR consisted of 35 cycles of $94{ }^{\circ} \mathrm{C}$ for $0.5 \mathrm{~min}, 64^{\circ} \mathrm{C}$ for $0.5 \mathrm{~min}$ and $72{ }^{\circ} \mathrm{C}$ for $1.5 \mathrm{~min}$. The PCR products were separated on a $1.5 \%$ agarose gel and viewed with ethidium bromide staining.

\section{Immunofluorescence staining and image analysis of VEGF receptors (KDR and Flt-1)}

HUSMCs and HUVECs were used for immunofluorescence staining. Cells were cultured after incubation for $24 \mathrm{~h}$ in serum-free DMEM, washed twice with PBS, fixed with $2 \%$ formaldehyde, and washed three times with calcium-magnesium-free PBS. After blocking with calcium-magnesium-free PBS containing 10\% FBS, antiKDR antibody (Santa Cruz Biotechnology, Santa Cruz, CA, USA) or anti-Flt-1 antibody (Santa Cruz Biotechnology) was applied at a 1:50 dilution for $60 \mathrm{~min}$ at room temperature. After the cells had been washed three times with calcium-magnesium-free PBS, fluorescein isothiocyanate-conjugated goat anti-rabbit immunoglobulin G (Sigma) was applied at a 1:50 dilution for $60 \mathrm{~min}$ at room temperature. Fluorescence image analysis was performed with an interactive laser cytometer (ACAS570; Meridian Instruments, Okemos, MI, USA).

In vitro angiogenesis assay (tube formation)

An experiment on tube formation was performed with a modification of the method of Hayashi et al. (1991). 
Inocula of $7 \times 10^{4}$ bovine endothelial cells in $0.5 \mathrm{ml}$ MEM (Life Technologies) containing 5\% FBS were plated on $0.5 \mathrm{ml}$ type I collagen gel (Koukenn, Tokyo, Japan) in a 24-well plate and incubated for $24 \mathrm{~h}$. After the medium had been aspirated, the cells were overlaid with $0.5 \mathrm{ml}$ type I collagen gel, then with $250 \mu \mathrm{l}$ MEM containing 5\% FBS and $250 \mu \mathrm{l}$ of 6 types of medium: (1) DMEM containing 10\% FBS with $20 \mathrm{ng} / \mathrm{ml}$ VEGF (human recombinant VEGF165); (2) DMEM containing 10\% FBS without VEGF; (3) culture medium of HUSMCs after incubation for 2 days in DMEM containing 10\% FBS with $20 \mathrm{ng} / \mathrm{ml}$ PDGF (conditioned medium); (4) the same as medium (3) but without PDGF; (5) the same as medium (3) but with the addition of $3 \mu \mathrm{g} / \mathrm{ml}$ VEGF-neutralizing antibody (IBL); (6) the same as medium (4) but with the addition of $3 \mu \mathrm{g} / \mathrm{ml}$ VEGF-neutralizing antibody. After incubation for 2 days, morphological changes were observed with a phase-contrast photo-microscope (LH50A; Olympus, Tokyo, Japan).

\section{Western blot analysis}

The active form of $\mathrm{p} 42 / \mathrm{p} 44$ mitogen-activated protein kinase (MAPK) protein and $\mathrm{p} 42 / \mathrm{p} 44$ MAPK protein were detected with a Western blot analysis. Serum-starved, sub-confluent cells in 10-cm Petri dishes were incubated for $5 \mathrm{~min}$ with $(10 \mathrm{ng} / \mathrm{ml})$ PDGF, without PDGF or with VEGF (50 $\mathrm{ng} / \mathrm{ml})$. HUSMCs were homogenized and the solution was clarified by centrifugation. The proteins in the supernatant were separated by SDS-PAGE $(10 \%$ gel), using $25 \mu \mathrm{g}$ total protein in each lane. The electrophoresed proteins were transferred to a nitrocellulose membrane. After blocking with 3\% BSA, an anti-active form of p42/p44 MAPK protein antibody (Promega, Madison, WI, USA) at a 1:5000 dilution or an anti-p42/p44 MAPK protein antibody (Santa Cruz) at a 1:1000 dilution was applied. The signal was visualized using a horseradish peroxidase-linked secondary antibody (Amersham), at a 1:5000 dilution, and enhanced chemiluminescence (ECL; Amersham).

\section{Statistical analysis}

The results are expressed as means \pm S.E.M. Statistical analyses were performed with ANOVA followed by Tukey's test or Dunnett's test. Tukey's test was used to compare two treatments, and Dunnett's test was used to compare control and treated cells. A value of $\mathrm{P}<0.05$ was considered statistically significant. All of the experiments were repeated at least three times.

\section{Results}

\section{Effect of PDGF on HUSMC proliferation and VEGF} production in HUSMCs

PDGF stimulated DNA synthesis in the cultured HUSMCs in a dose-dependent manner. At $10 \mathrm{ng} / \mathrm{ml}$, (a)

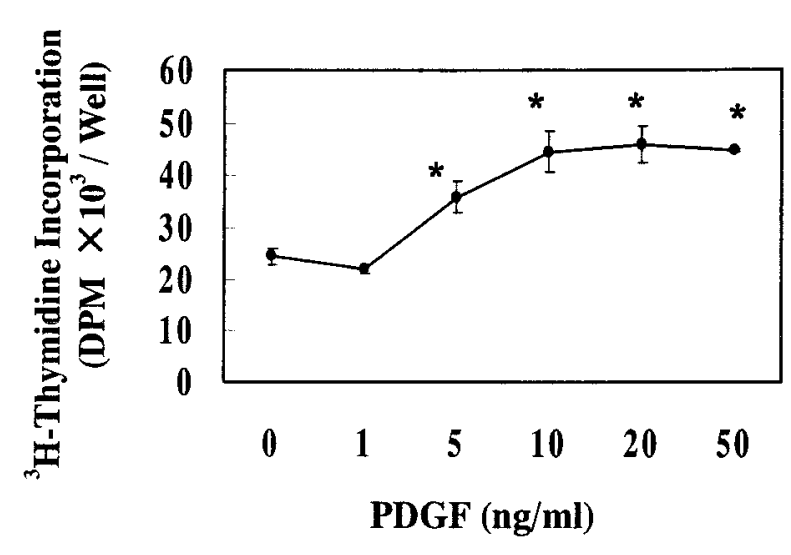

(b)

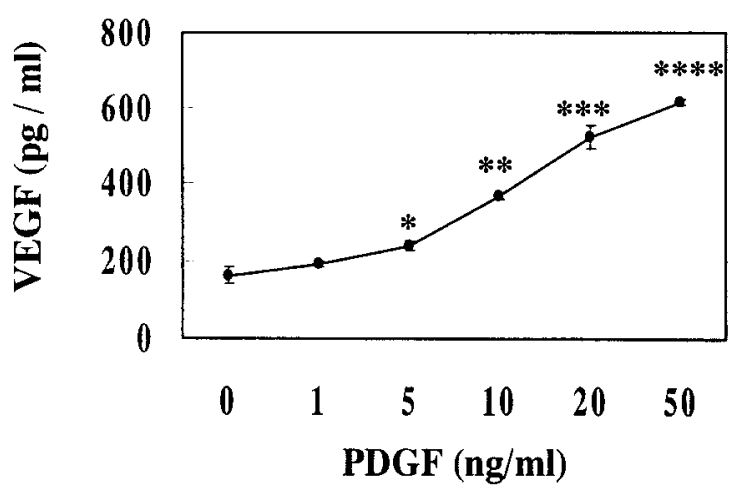

Figure 1 (a) Effect of PDGF on $\left[{ }^{3} \mathrm{H}\right]$ thymidine incorporation in HUSMCs. (b) Effect of PDGF on VEGF secretion in HUSMCs determined by the ELISA method. The cultures were treated with PDGF for $24 \mathrm{~h}$ in serum-free DMEM, with recombinant human PDGF-BB at concentrations from $1 \mathrm{ng} / \mathrm{ml}$ to $50 \mathrm{ng} / \mathrm{ml}$, or with vehicle (control). Data are expressed as means \pm S.E.M. ${ }^{*} P<0.05$ compared with the control. ${ }^{* *} P<0.05$ compared with the control and $5 \mathrm{ng} / \mathrm{ml}$ PDGF. ${ }^{* *} P<0.05$ compared with the control, $5 \mathrm{ng} / \mathrm{ml}$ PDGF, and $10 \mathrm{ng} / \mathrm{ml}$ PDGF. ${ }^{* * *} P<0 \cdot 05$ compared with the control, $5 \mathrm{ng} / \mathrm{ml}$ PDGF, $10 \mathrm{ng} / \mathrm{ml}$ PDGF, and $20 \mathrm{ng} / \mathrm{ml}$ PDGF.

PDGF induced an approximately $1 \cdot 5$-fold increase in $\left[{ }^{3} \mathrm{H}\right]$ thymidine incorporation in HUSMCs compared with the control, and at higher doses the effect of PDGF plateaued (Fig. 1a). The stimulatory effect of PDGF on cell proliferation was confirmed by the increase in cell number (control: $42.2 \pm 0.9 \times 10^{3} /$ well; PDGF: $56 \cdot 3 \pm 2 \cdot 3 \times 10^{3} /$ well $)$.

Because myometrial smooth muscle in ewes showed immunostaining for VEGF (Reynolds et al. 1998), we investigated whether PDGF affected VEGF secretion from HUSMCs. We measured the content of VEGF in cultured media from cells after incubation for $24 \mathrm{~h}$ in serum-free DMEM with various doses of PDGF. At concentrations 


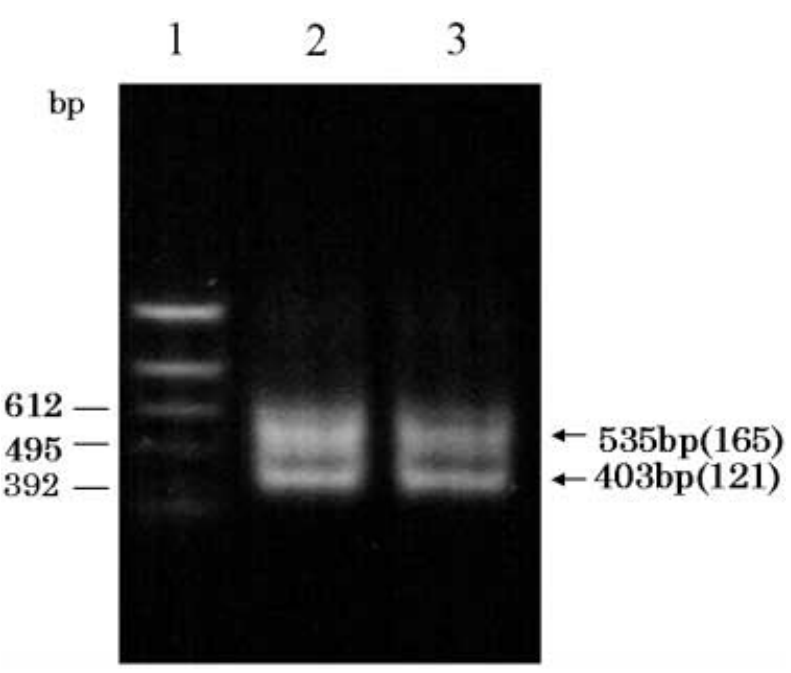

Figure 2 Effect of PDGF on mRNA of VEGF isoforms. Serumstarved, sub-confluent HUSMCs were treated, or not treated with, recombinant human PDGF-BB $(20 \mathrm{ng} / \mathrm{ml})$ for $24 \mathrm{~h}$. Total RNA was subjected RT-PCR. The PCR products were separated on a $1.5 \%$ agarose gel and visualized using ethidium bromide staining. Lanes: 1, DNA marker; 2, unstimulated cells; 3, PDGF-BB (20 ng/ml). The presence of $403 \mathrm{bp}$ and $535 \mathrm{bp}$ amplicons confirmed the presence of mRNA for VEGFs 121 and 165.

above $5 \mathrm{ng} / \mathrm{ml}$, PDGF induced VEGF secretion in a dose-dependent manner (Fig. 1b). In contrast to cell proliferation, VEGF secretion increased linearly with the dose of PDGF. PDGF at $10 \mathrm{ng} / \mathrm{ml}$ induced a $2 \cdot 3$-fold increase in VEGF secretion, and at $50 \mathrm{ng} / \mathrm{ml}$ it induced a $3 \cdot 8$-fold increase relative to the control, respectively.
However, treatment of HUSMCs with 17ß-estradiol, which is known as an inducer of VEGF production in endometrium (Shifren et al. 1996, Huang et al. 1998), failed to stimulate VEGF secretion at any of the doses used in this experiment (data not shown).

By using RT-PCR, we observed the expression of VEGF isoforms in HUSMCs cultured in the presence or absence of PDGF (Fig. 2). The two most common VEGF isoforms, VEGF121 and VEGF165, were detected. The presence of $403 \mathrm{bp}$ and $535 \mathrm{bp}$ amplicons confirmed the presence of mRNA for VEGF121 and VEGF 165. PDGF-stimulated cells showed the same pattern of VEGF isoforms when compared with the unstimulated cells.

\section{Effect of VEGF on proliferation of HUSMCs}

To examine the effect of VEGF on the functions of HUSMCs, the expression of VEGF receptors (Flt-1 and KDR) was first measured by the indirect immunofluorescence method. The expression of VEGF receptors was analyzed quantitatively using a laser cytometer (ACAS570; Meridian Instruments, Okemos, MI, USA) (Fig. 3). Although the fluorescence intensities in HUSMCs were lower than those in HUVECs, it showed that the expression of KDR was detectable in HUSMCs.

The treatment of HUSMCs with $20 \mathrm{ng} / \mathrm{ml}$ VEGF failed to increase the $\left[{ }^{3} \mathrm{H}\right]$ thymidine incorporation. In contrast, VEGF induced an approximately 1.7-fold increase in $\left[{ }^{3} \mathrm{H}\right]$ thymidine incorporation in HUVECs compared with the control (Fig. 4a). It is interesting that treatment of the cells with antibody against VEGF raised

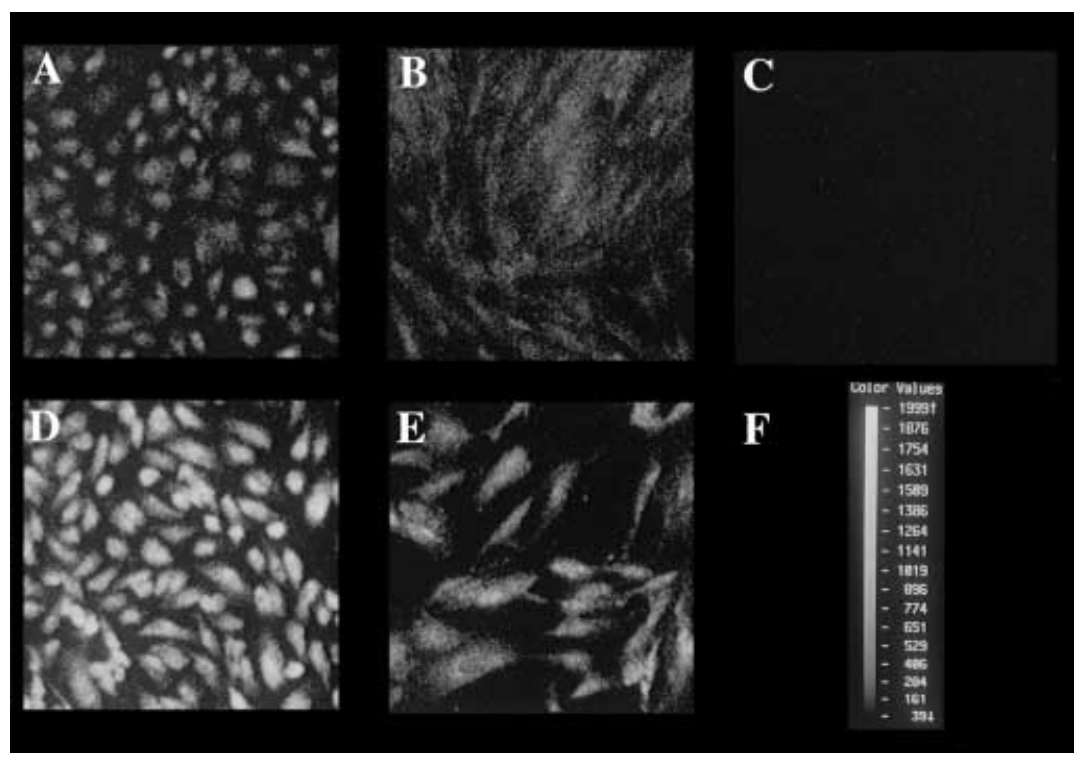

Figure 3 Immunofluorescence staining of VEGF receptors (Flt-1 and KDR), and image analysis. (A) Flt-1 in HUVECs, (B) Flt-1 in HUSMCs, (C) negative control, (D) KDR in HUVECs, (E) KDR in HUSMCs, (F) color value. 
(a)

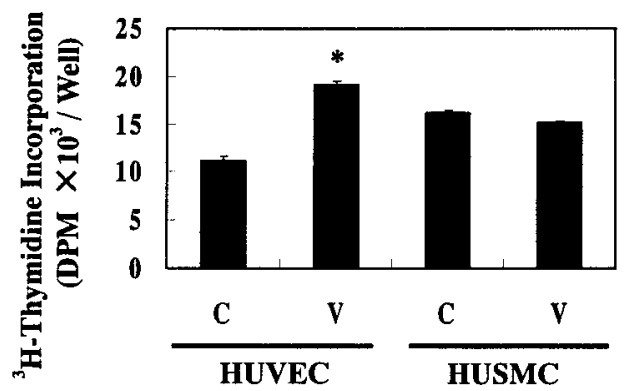

(b)

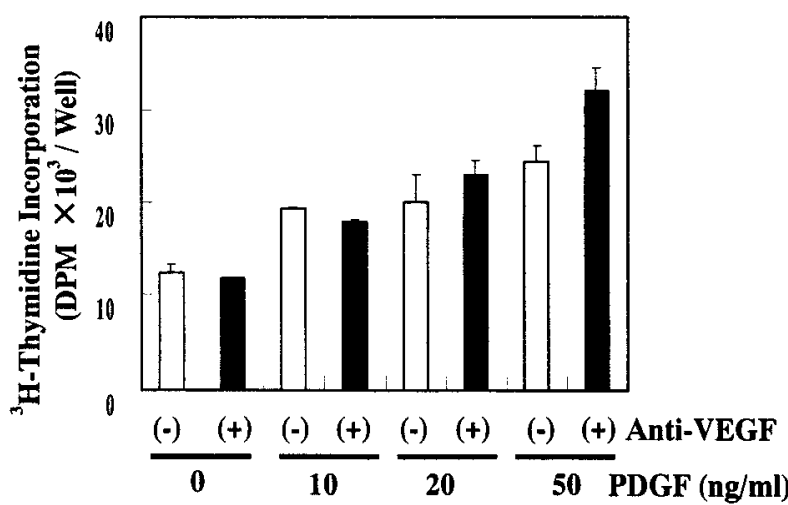

Figure 4 (a) Effect of VEGF on $\left[{ }^{3} \mathrm{H}\right]$ thymidine incorporation in HUVECs or HUSMCs. The cultures were treated with VEGF for $24 \mathrm{~h}$ in serum-free DMEM, recombinant human VEGF 165 $(20 \mathrm{ng} / \mathrm{ml})$, or vehicle (control). $\mathrm{C}=$ vehicle; $\mathrm{V}=\mathrm{VEGF}$ $(20 \mathrm{ng} / \mathrm{ml}) .{ }^{*} P<0.05$ compared with the control. (b) Effect of PDGF and additional VEGF-neutralizing antibody on $\left[{ }^{3} \mathrm{H}\right]$ thymidine incorporation in HUSMCs. The cultures were treated with PDGF for $24 \mathrm{~h}$ in serum-free DMEM, recombinant human PDGF-BB (10, $20,50 \mathrm{ng} / \mathrm{ml}$ ), or vehicle (control) and with (solid bars) or without (open bars) additional VEGF-neutralizing antibody $(3 \mu \mathrm{g} / \mathrm{ml})$. Data are expressed as means \pm S.E.M.

the cell proliferation linearly even at PDFG concentrations above $10 \mathrm{ng} / \mathrm{ml}$ (Fig. 4b).

In vitro angiogenesis induced by conditioned medium of HUSMCS

To investigate whether the VEGF secreted from HUSMCs was functionally active, the conditioned medium of HUSMCs in the presence or absence of PDGF was applied to an in vitro tube-formation assay system. As previously described, when bovine endothelial cells were cultured between type I collagen for 2 days with VEGF, a tube-like formation was produced (Fig. 5D) (Hayashi et al. 1991). The cellular organization of the tube-like formation was slightly stimulated by the conditioned medium of HUSMCs (Fig. 5B), and was stimulated even more by the cultured medium of PDGF-treated HUSMCs (Fig. 5E).
The stimulatory effect of both conditioned media was abolished by the simultaneous addition of a neutralizing antibody against VEGF (Fig. 5C and F). These results indicate that PDGF stimulates the secretion of functionally active VEGF proteins.

Involvement of MAPK and PKC in the stimulatory effects of PDGF on proliferation and VEGF secretion in HUSMCs

To determine which signal pathways are involved in the stimulatory effects of PDGF on the proliferation of, and VEGF secretion in, HUSMCs, the cell lysates were subjected to Western blot analysis for p42/p44 MAPK and phosphorylated MAPK (an active form of MAPK). HUSMCs were placed in serum-free DMEM for $24 \mathrm{~h}$ and then pulsed with PDGF for $5 \mathrm{~min}$. Cell lysates were immunoblotted with an antibody that recognized phosphorylated MAPK. Incubation of HUSMCs with $50 \mathrm{ng} / \mathrm{ml}$ human recombinant VEGF165 did not cause any change in the basal level, but treatment with $10 \mathrm{ng} / \mathrm{ml}$ PDGF resulted in an increase in phosphorylation of MAPK (Fig. 6). In contrast, the amount of immunoreactive MAPK was not changed by any of these treatments. Next, to determine if the activation of MAPK mediates the proliferation and VEGF secretion in HUSMCs induced by PDGF, the cells were treated with PD098059, a specific inhibitor of MAPKK. In addition, we also examined the effect of GF109203X (a specific PKC inhibitor) on the proliferation and VEGF secretion induced by PDGF. $\left[{ }^{3} \mathrm{H}\right]$ thymidine incorporation was significantly reduced by both PD098050 and GF109203X, suggesting that the MAPK and PKC pathways are involved in the proliferation of HUSMCs induced by PDGF (Fig. 7a). In contrast, VEGF secretion was also reduced to the basal level by PD098050 but was not significantly reduced by GF109203X, suggesting that the MAPK pathway is the predominant pathway in PDGF-induced VEGF secretion (Fig. 7b).

\section{Discussion}

PDGF, fibroblast growth factor, epidermal growth factor and insulin-like growth factor have been postulated to act as mitogens of myometrial smooth muscle cells, and to play roles in the pathogenesis of certain conditions, e.g. in leiomyomata (Rossi et al. 1992, Tang et al. 1994, Mangrulkar et al. 1995). The expression of their growthfactor receptors has been also demonstrated in HUSMCs (Fayed et al. 1989, Rossi et al. 1992, Tang et al. 1994). In this work, we selected PDGF as a mitogen of HUSMCs because it is known to be the most powerful among the mitogens of smooth muscle cells. The PDGF receptor appears in two forms, each having different affinities, designated as the $\alpha$ - and $\beta$-types. Immunohistochemical studies indicated that primary HUSMCs cultures 

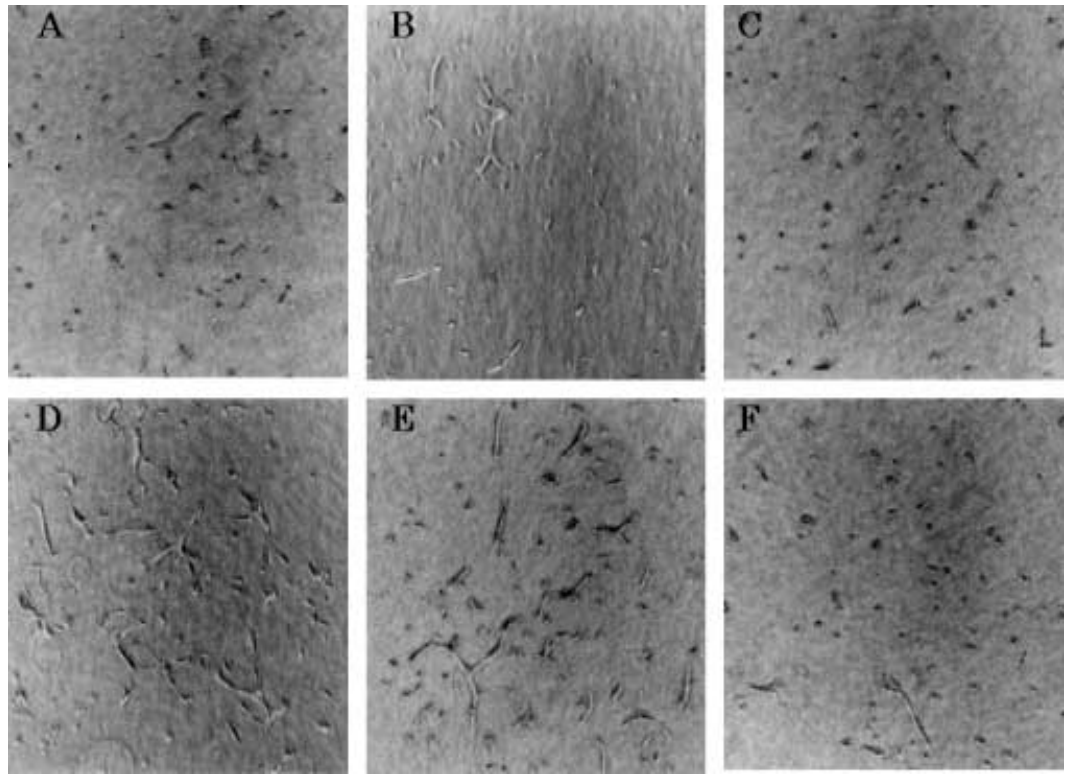

Figure 5 In vitro angiogenesis assay (tube formation). Bovine endothelial cells were cultured between two layers of type I collagen gel as described in Materials and Methods. The cells were cultured for 2 days in MEM containing 5\% FBS and various media. (A) DMEM containing 10\% FBS. (B) Cultured medium of HUSMCs after incubation for 2 days in DMEM containing 10\% FBS without stimulation with PDGF. (C) Cultured medium of HUSMCs after incubation for 2 days in DMEM containing 10\% FBS without stimulation with PDGF and with additional VEGF-neutralizing antibody $(3 \mu \mathrm{g} / \mathrm{ml})$. (D) DMEM containing $10 \%$ FBS in the presence of VEGF $20 \mathrm{ng} / \mathrm{ml}$. (E) Cultured medium of HUSMCs after incubation for 2 days in DMEM containing 10\% FBS in the presence of PDGF $(20 \mathrm{ng} / \mathrm{ml})$. (F) Cultured medium of HUSMCs after incubation for 2 days in DMEM containing 10\% FBS in the presence of PDGF $(20 \mathrm{ng} / \mathrm{ml})$ and additional VEGF-neutralizing antibody $(3 \mu \mathrm{g} / \mathrm{ml})$.

expressed the $\beta$-receptor of PDGF, but not the $\alpha$-receptor (Rossi et al. 1992). The $\beta$-type receptor binds to PDGF-BB with high affinity and to PDGF-AB (hetero-

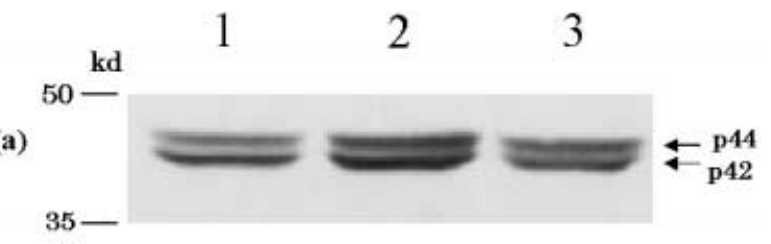

(b)

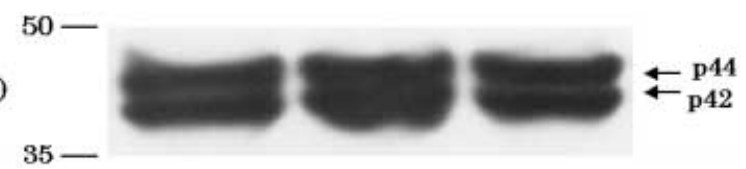

Figure 6 The active form of (phosphorylated) p42/p44 MAPK protein and p42/p44 MAPK protein were detected using a Western blot analysis. Serum-starved, sub-confluent cells were treated, or not treated, with recombinant human PDGF-BB $(10 \mathrm{ng} / \mathrm{ml})$ or VEGF $(50 \mathrm{ng} / \mathrm{ml})$ for $5 \mathrm{~min}$. Total protein $(25 \mu \mathrm{g})$ isolated from HUSMCs was loaded in each lane. (a) Active form of p42/p44 MAPK protein. (b) p42/p44 MAPK protein. Lanes: 1, unstimulated cells; 2, PDGF-BB (10 ng/ml); 3, VEGF $(50 \mathrm{ng} / \mathrm{ml})$. dimer of PDGF-A and PDGF-B) with low affinity. Therefore, in this work PDGF-BB was used. Treatment of HUSMCs with PDGF-BB significantly raised $\left[{ }^{3} \mathrm{H}\right]$ thymidine incorporation, but at concentrations above $10 \mathrm{ng} / \mathrm{ml}$ the stimulatory effect leveled off. This dose-dependency of PDGF is consistent with the results of Rossi et al. (1992), who demonstrated that PDGF-AB stimulated DNA synthesis of HUSMCs, with maximal stimulation at $10 \mathrm{ng} / \mathrm{ml}$ PDGF-AB, and that no significant stimulation occurred at higher concentrations. It is widely accepted that treatment of cells with PDGF triggers phosphorylation cascades that lead to activation of MAPK and PKC (Kazlauskas \& Cooper 1988, Choudhury et al. 1993, De \& Iyengar 1994, Lubinus et al. 1994). As expected, PDGF activated MAPK (Fig. 6), and the enhanced $\left[{ }^{3} \mathrm{H}\right]$ thymidine incorporation by PDGF was abolished by inhibitors of either MAPKK or PKC (Fig. 7a).

The conditioned medium of HUSMCs cultured with PDGF enhanced the tube-forming activity of bovine endothelial cells cultured within type I collagen. The stimulatory effect of the conditioned medium was abolished by anti-VEGF antibody (Fig. 5). Therefore, we carried out RT-PCR and detected the production of VEGF 121 and VEGF 165 in the cells (Fig. 2). There are 
(a)

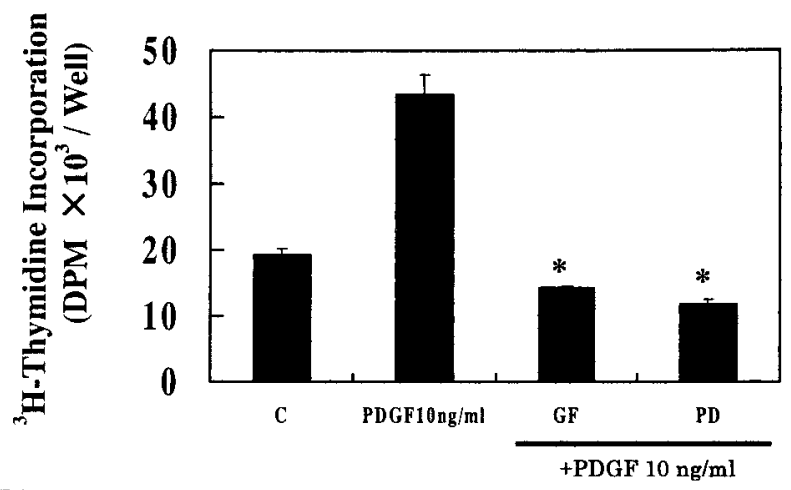

(b)

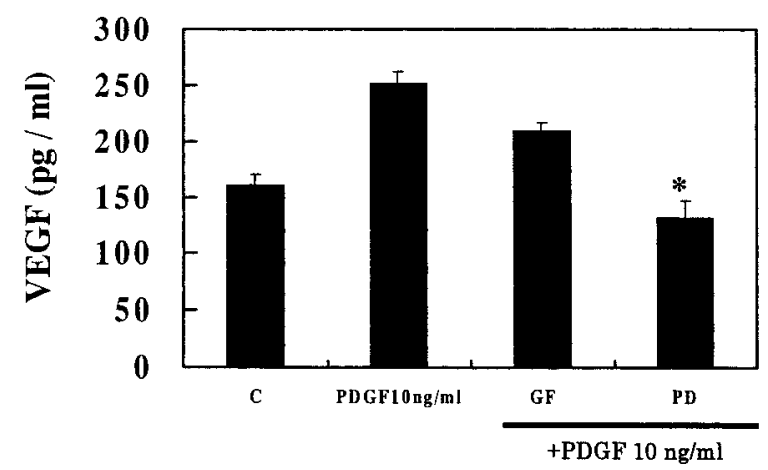

Figure 7 Effects of MAPKK and PKC inhibitors on PDGF stimulation. The cultures were preincubated for $30 \mathrm{~min}$ with the specific MAPKK inhibitor PD $098059(100 \mu \mathrm{M})$ or with the specific PKC inhibitor GF 109203X (5 $\mu \mathrm{M})$ prior to $24 \mathrm{~h}$ incubation with $10 \mathrm{ng} / \mathrm{ml}$ PDGF. (a) Effect of PDGF on HUSMC $\left[{ }^{3} \mathrm{H}\right]$-thymidine incorporation. (b) Effect of PDGF on secreted VEGF proteins from HUSMCs, determined by the ELISA method. $\mathrm{GF}=\mathrm{GF} 109203 \mathrm{X}(5 \mu \mathrm{M}) ; \mathrm{PD}=\mathrm{PD} 098059(100 \mu \mathrm{M})$. Data are expressed as means \pm S.E.M. ${ }^{*} P<0.05$ compared with PDGF-BB (10 ng/ml).

five isoforms of VEGF (from the number of amino acids), namely VEGF 121, 145, 165, 189 and 206. Among them, VEGF 121, 165 and 189 were expressed in many kinds of cells, and VEGF 206 was detectable in fetal liver (Keck et al. 1989, Houck et al. 1991, Tischer et al. 1991). VEGFs 121, 165 and 189 were detected in human myometrium (Charnock et al. 1993, Harrison et al. 1995). Charnock et al. (1993) also detected VEGF 145. Our data were not coincident with these results. The difference in expression may be due to the origin of the samples, as cultured myometrial smooth muscle cells were used in the present work, whereas myometrial tissue was used in the other studies. Treatment of HUSMCs with PDGF did not change the ratio of VEGF 121 to VEGF 165, in spite of the fact that the production of immunoreactive VEGF was enhanced by PDGF.
The dose-dependent curves linking DNA synthesis and VEGF production stimulated by PDGF were different; that is, the effect of PDGF on cell proliferation leveled off at $10 \mathrm{ng} / \mathrm{ml}$, whereas its effect on VEGF production continued to increase linearly at concentrations above $10 \mathrm{ng} / \mathrm{ml}$. This difference leads to us to the following two hypotheses: (1) VEGF released by the treatment of PDGF at concentrations above $10 \mathrm{ng} / \mathrm{ml}$ negatively regulates the proliferation of HSUMCs induced by PDGF; and (2) the different signaling pathways are involved in the stimulatory effects of PDGF on DNA synthesis and VEGF production. The first hypothesis might be supported by the data from the treatment with anti-VEGF antibody (Fig. 4b). In the recent study, the treatment of sinusoidal endothelial cells with VEGF induced apoptosis via PKC $\delta$ activation (M Shibuya, personal communication). Therefore, though it is possible that VEGF prevents cell growth or survival, further studies are necessary to reveal the mechanism by which VEGF downregulates PDGF-induced cell proliferation in HUSMCs.

Several papers have demonstrated the involvement of PKC and MAPK in PDGF-induced cell proliferation (Choudhury et al. 1993, De \& Iyengar 1994, Lubinus et al. 1994). Our data also support the involvement of PKC and MAPK in the proliferation of HUSMCs induced by PDGF-BB. Recently, Milanini et al. (1998) have shown that $\mathrm{p} 42 / \mathrm{p} 44$ MAPK plays a key role in the expression of VEGF. PKC is involved in the induction of VEGF expression by phorbol myristate acetate (Hata et al. 1999). It is possible that among several PKC isomers, $\mathrm{PKC} \zeta$ activation and translocation are important in VEGF expression. It has been reported that PDGF activated PKC $\zeta$ in human dermal fibroblasts $(\mathrm{Xu}$ et al. 1996). A Western blot analysis showed that PKC $\alpha$ and PKC $\zeta$ were the dominant PKC isomers expressed in human myometrial cells (Tertrin et al. 1999). These reports suggest that VEGF production induced by PDGF is dependent on PKC activation. However, in our experiment, treatment of HUSMCs with GF 109203X failed to abolish the production of VEGF induced by PDGF. This inhibitor was previously shown to inhibit PKCל activity (Xu et al. 1996). The reason why PKC is not involved in PDGF-induced VEGF production in HUSMCs is unclear, but our experiment indicates that PDGF raises VEGF secretion predominantly through MAPK activation. Reynolds et al. (1998) reported that $17 \beta$-estradiol enhanced VEGF mRNA expression in ovariectomized ewes in vivo. Therefore, to confirm this phenomenon, HUSMCs were treated with $17 \beta$-estradiol, and VEGF protein levels in the medium were measured. However, we did not observe a stimulatory effect of $17 \beta$-estradiol on VEGF secretion. The different observations are probably due to a difference in the experimental conditions.

In conclusion, PDGF stimulates the proliferation of, and VEGF secretion in, HUSMCs, and angiogenesis via 
VEGF production is probably important for uterine myometrial vascularization.

\section{References}

Alessi DR, Cuenda A, Cohen P, Dudley DT \& Saltiel AR 1995 PD 098059 is a specific inhibitor of the activation of mitogen-activated protein kinase kinase in vitro and in vivo. Journal of Biological Chemistry $27027489-27494$.

Brogi E, Wu T, Namiki A \& Isner JM 1994 Indirect angiogenic cytokines upregulate VEGF and bFGF gene expression in vascular smooth muscle cells, whereas hypoxia upregulates VEGF expression only. Circulation 90 649-652.

Charnock JD, Sharkey AM, Rajput WJ, Burch D, Schofield JP, Fountain SA, Boocock CA \& Smith SK 1993 Identification and localization of alternately spliced mRNAs for vascular endothelial growth factor in human uterus and estrogen regulation in endometrial carcinoma cell lines. Biology of Reproduction $\mathbf{4 8}$ $1120-1128$.

Chen L, Lindner HR \& Lancet M 1973 Mitogenic action of oestradiol-17 beta on human myometrial and endometrial cells in long-term tissue cultures. Journal of Endocrinology 59 87-97.

Choudhury GG, Biswas P, Grandaliano G \& Abboud HE 1993 Involvement of PKC-alpha in PDGF-mediated mitogenic signaling in human mesangial cells. American Journal of Physiology 265 F634-F642.

De VM \& Iyengar R 1994 Activated Gq-alpha potentiates plateletderived growth factor-stimulated mitogenesis in confluent cell cultures. Journal of Biological Chemistry 269 19671-19674.

Fayed YM, Tsibris JC, Langenberg PW \& Robertson AJ 1989 Human uterine leiomyoma cells: binding and growth responses to epidermal growth factor, platelet-derived growth factor, and insulin. Laboratory Investigation 60 30-37.

Harrison WM, Sharkey AM, Charnock JD \& Smith SK 1995 Localization and quantification of vascular endothelial growth factor messenger ribonucleic acid in human myometrium and leiomyomata. Journal of Clinical Endocrinology and Metabolism $\mathbf{8 0}$ 1853-1858.

Hata Y, Rook SL \& Aiello LP 1999 Basic fibroblast growth factor induces expression of VEGF receptor KDR through a protein kinase $\mathrm{C}$ and $\mathrm{p} 44 / \mathrm{p} 42$ mitogen-activated protein kinase-dependent pathway. Diabetes 48 1145-1155.

Hayashi JN, Ito H, Kanayasu T, Asuwa N, Morita I, Ishii T \& Murota S 1991 Effects of glucose on migration, proliferation and tube formation by vascular endothelial cells. Virchows Archiv. B, Cell Pathology Including Molecular Pathology 60 245-252.

Houck KA, Ferrara N, Winer J, Cachianes G, Li B \& Leung DW 1991 The vascular endothelial growth factor family: identification of a fourth molecular species and characterization of alternative splicing of RNA. Molecular Endocrinology 5 1806-1814.

Huang JC, Liu DY \& Dawood MY 1998 The expression of vascular endothelial growth factor isoforms in cultured human endometrial stromal cells and its regulation by 17 beta-oestradiol. Molecular Human Reproduction 4 603-607.

Kawaguchi K, Fujii S, Konishi I, Okamura H \& Mori T 1985 Ultrastructural study of cultured smooth muscle cells from uterine leiomyoma and myometrium under the influence of sex steroids. Gynecologic Oncology 21 32-41.

Kazlauskas A \& Cooper JA 1988 Protein kinase C mediates plateletderived growth factor-induced tyrosine phosphorylation of $\mathrm{p} 42$. Journal of Cell Biology 106 1395-1402.

Keck PJ, Hauser SD, Krivi G, Sanzo K, Warren T, Feder J \& Connolly DT 1989 Vascular permeability factor, an endothelial cell mitogen related to PDGF. Science 246 1309-1312.
Lubinus M, Meier KE, Smith EA, Gause KC, LeRoy EC \& Trojanowska M 1994 Independent effects of platelet-derived growth factor isoforms on mitogen activated protein kinase activation and mitogenesis in human dermal fibroblasts. Journal of Biological Chemistry 269 9822-9825.

Mangrulkar RS, Ono M, Ishikawa M, Takashima S, Klagsbrun M \& Nowak RA 1995 Isolation and characterization of heparin-binding growth factors in human leiomyomas and normal myometrium. Biology of Reproduction 53 636-646.

Milanini J, Vinals F, Pouyssegur J \& Pages G 1998 p42/p44 MAP kinase module plays a key role in the transcriptional regulation of the vascular endothelial growth factor gene in fibroblasts. Journal of Biological Chemistry 273 18165-18172.

Moss NS \& Benditt EP 1975 Human atherosclerotic plaque cells and leiomyoma cells. Comparison of in vitro growth characteristics. American Journal of Pathology 78 175-190.

Pang L, Sawada T, Decker SJ \& Saltiel AR 1995 Inhibition of MAP kinase kinase blocks the differentiation of $\mathrm{PC}-12$ cells induced by nerve growth factor. Journal of Biological Chemistry $\mathbf{2 7 0}$ 13585-13588.

Reynolds LP, Kirsch JD, Kraft KC, Knutson DL, McClaflin WJ \& Redmer DA 1998 Time-course of the uterine response to estradiol-17 beta in ovariectomized ewes: uterine growth and microvascular development. Biology of Reproduction 59 606-612.

Rossi MJ, Chegini N \& Masterson BJ 1992 Presence of epidermal growth factor, platelet-derived growth factor, and their receptors in human myometrial tissue and smooth muscle cells: their action in smooth muscle cells in vitro. Endocrinology 130 1716-1727.

Shifren JL, Tseng JF, Zaloudek CJ, Ryan IP, Meng YG, Ferrara N, Jaffe RB \& Taylor RN 1996 Ovarian steroid regulation of vascular endothelial growth factor in the human endometrium: implications for angiogenesis during the menstrual cycle and in the pathogenesis of endometriosis. Journal of Clinical Endocrinolog $\gamma$ and Metabolism $\mathbf{8 1}$ 3112-3118

Stavri GT, Hong Y, Zachary IC, Breier G, Baskerville PA, Yla HS, Risau W, Martin JF \& Erusalimsky JD 1995 Hypoxia and platelet-derived growth factor-BB synergistically upregulate the expression of vascular endothelial growth factor in vascular smooth muscle cells. FEBS Letters 358 311-315.

Tang XM, Rossi MJ, Masterson BJ \& Chegini N 1994 Insulin-like growth factor I (IGF-I), IGF-I receptors, and IGF binding proteins 1-4 in human uterine tissue: tissue localization and IGF-I action in endometrial stromal and myometrial smooth muscle cells in vitro. Biology of Reproduction 50 1113-1125.

Tertrin CC, Eude I, Fournier T, Paris B, Breuiller FM \& Ferre F 1999 Contribution of protein kinase C to ET-1-induced proliferation in human myometrial cells. American Journal of Physiology 267 E503-E511.

Tischer E, Mitchell R, Hartman T, Silva M, Gospodarowicz D, Fiddes JC \& Abraham JA 1991 The human gene for vascular endothelial growth factor. Multiple protein forms are encoded through alternative exon splicing. Journal of Biological Chemistry 266 11947-11954.

Toullec D, Pianetti P, Coste H, Bellevergue P, Grand PT, Ajakane M, Baudet V, Boissin P, Boursier E, Loriolle F, Duhamel L, Charon D \& Kirilovsky J 1991 The bisindolylmaleimide GF 109203X is a potent and selective inhibitor of protein kinase C. Journal of Biological Chemistry 266 15771-15781.

Xu J, Zutter MM, Santoro SA \& Clark RA 1996 PDGF induction of alpha 2 integrin gene expression is mediated by protein kinase C-zeta. Journal of Cell Biology 134 1301-1311.

Received in final form 4 December 2000

Accepted 13 December 2000 